\title{
PENGARUH PEMBERIAN BERBAGAI POLLARD TEROLAH TERHADAP PERTUMBUHAN ORGAN PENCERNAAN AYAM BROILER UMUR 7 MINGGU
}

\author{
THE EFFECT OF PROCESSED POLLARD ADMINISTRATION TOWARD DIGESTIVE \\ ORGAN GROWTH OF 7 WEEKS AGE BROILERS
}

\author{
C. S. Utama, B. Sulistiyanto dan T. A. Wicaksono \\ Departemen Peternakan Fakultas Peternakan dan Pertanian Universitas Diponegoro \\ Kampus Tembalang, Semarang 50275 \\ Email : cahyasetyautama@gmail.com
}

Diterima: 17 Juni 2019, Direvisi: 15 Juli 2019, Disetujui: 24 Juli 2019

\begin{abstract}
ABSTRAK
Penelitian bertujuan mengkaji pengaruh penggunaan pollard terolah dalam ransum terhadap pertumbuhan organ proventrikulus, ventrikulus, duodenum, jejenum dan ileum pada ayam broiler umur 7 minggu. Materi penelitian menggunakan 200 ekor ayam broiler umur 7 minggu dengan bobot rata-rata $859 \pm 59 \mathrm{~g}$ dengan tiap unit percobaan terdiri dari $8-9$ ekor. Rancangan yang digunakan adalah rancangan acak lengkap (RAL) dengan 5 perlakuan dan 3 ulangan. Perlakuan yang diberikan yaitu $(\mathrm{T} 0=$ Pakan Pabrik, $\mathrm{T} 1=$ Ransum dengan pollard tanpa diolah, $\mathrm{T} 2=$ Ransum dengan pollard diolah secara fisik , T3 = Ransum dengan pollard terolah fisik dan biologi $40 \%$, dan T4= Ransum dengan pollard terolah fisik dan biologi 60\%) dengan 3 ulangan. Hasil penelitian menunjukkan bahwa pemberian pollard terolah secara fisik dan biologis belum mampu meningkatkan semua bobot relatif organ pencernaan ayam broiler umur 7 minggu. Pada organ proventrikulus pakan perlakuan mampu meningkatkan bobot relatif organ pencernaan ayam broiler, namun bobot relatif proventrikulus yang dihasilkan masih tergolong normal. Pengukuran bobot organ ayam broiler perlu dilakukan per minggu untuk mengetahui laju peningkatan bobot relatif organ pencernaan yang optimal, sehingga diperoleh data maksimal pertumbuhan organ ayam broiler secara tepat.
\end{abstract}

Kata Kunci :broiler, organ pencernaan, pollard, fermentasi

\section{ABSTRACT}

The study aimed to examine the effect of using pollard in rations on the growth of proventricular, ventricular, duodenal, jejunal and ileal organs in 7-week-old broiler chickens. The research material used 200 broiler chickens aged 7 weeks with an average weight of $859 \pm 59 \mathrm{~g}$ with each experimental unit consisting of 8 - 9 tails. The design used was a completely randomized design with 5 treatments and 3 replications. Treatment is given $(T 0=$ Comersial feeds, $T 1=$ Feed with pollard without processing, T2 $=$ Feed with pollard treated physically, $T 3=$ Feed with pollard treated physically and biologically, and T4 = Feed with pollard treated physically and biology $60 \%)$ and 3 replications. Based on the results of the study it can be concluded that the administration of pollard treated physically and biologically has not been able to increase all the relative weights of the digestive organs of broiler chickens aged 7 weeks. In the proventriculus organ, the treatment can increase the relative weight of broiler digestive organs, but the relative weight of the proventriculus produced is still relatively normal. Measurement of broiler chicken organ weight needs to be done per week to determine the rate of increase in the relative weight of 
the optimal digestive organs, so that the maximum data on the growth of broiler organs are obtained optimally.

Keywords: broiler, digestive organs, pollard, fermentation

\section{PENDAHULUAN}

Ayam broiler merupakan turunan atau persilangan dari bangsa-bangsa ayam yang memiliki daya produktifitas tinggi, terutama dalam memproduksi daging ayam (Yuwanta, 2004). Hardjoswaro dan Rukminasih (2000), menyatakan bahwa ayam broiler dapat digolongkan ke dalam kelompok unggas penghasil daging artinya dipelihara khusus untuk menghasilkan daging. Menurut Rasyaf (2008), ayam pedaging adalah ayam pejantan dan betina muda yang beumur dibawah 6 minggu ketika dijual dengan bobot badan tertentu, mempunyai pertumbuhan yang cepat, serta dada yang lebar dengan timbunan daging yang banyak. Ayam broiler di Indonesia jarang sekali mengkonsumsi polllard, padahal pollard merupakan sumber energi yang lebih baik dari pada bekatul.

Pollard merupakan bahan pakan sumber energi yang berasal dari limbah penggilingan gandum. Pollard memiliki kandungan nutrisi yaitu protein $16,29 \%$, NDF 38,40\%, ADF 10,48\%, selulosa $7,18 \%$, lignin 3,09\% dan Energi 16,40\% (Raharjo et al., 2000). Pollard adalah limbah hasil industri pertanian dari penggilingan gandum sebagai sumber energi yang tinggi dan mengandung polisakarida struktural seperti selulosa, hemiselulosa, selebiosa, lignin dan silika,sehingga pollard sangat cocok diberikan untuk ternak ruminansia (Utama et al., 2013). Karbohidrat yang tinggi pada pollard memungkinkan mikroorganisme memanfaatkan substrat untuk bertahan hidup (Nurdianto et al., 2015). Kandungan serat yang tinggi dalam pollard menyebabkan penggunaannya dalam pakan unggas dibatasi. Kandungan serat
(NDF dan ADF) yang tinggi dalam pollard akan menyebabkan terjadinya peningkatan sekresi nitrogen endogenous, sehingga penyerapan nitrogen akan mengalami penurunan.

Peningkatan nilai nutrisi pollard dilakukan dengan memperbaiki struktur polisakarida melalui pengolahan secara fisik yaitu pengukusan dan fermentasi yaitu pemeraman dengan probiotik limbah kubis terfermentasi (Utama et al., 2017; Utama et al., 2018b). Pengolahan secara fisik dengan cara steamingmenggunakan autoclave dapat mengubah struktur kimia dan fisik pollard yang disebabkan oleh tekanan panas. Pollard yang diolah dengan pemanasan mampu meningkatkan gelatinasi pati dan menurunkan zat antinutrisi serta meningkatkan konsumsi pakan (Sulistiyanto et al., 2017). Fermentasi memiliki beberapa keuntungan yaitu memecah protein menjadi mono peptida dan asam amino, berperan dalam menghambat bakteri patogen yang mampu tumbuh dan berkembang biak dalam saluran pencernaan (Utama et al.,2013). Limbah kubis terfermentasi memiliki potensi sebagai probiotik karena mengandung bakteri asam laktat yaitu Lactobacillus brevis, lactobacillus plantarum, Rhizopus oryze dan Saccharomyces cerevisedan mampu mendegradasi selulosa (Utama et al 2018a dan Utama et al., 2018b).

\section{METODE Materi Penelitian}

Materi yang digunakan pada penelitian adalah ayam broiler sebanyak 200 ekor Strain MB 202 dengan bobot 
awal $38 \pm 0,32$ gram. Peralatan yang digunakan terdiri dari kandang ayam untuk tempat pemeliharaan ayam broiler yang dilengkapi dengan tempat pakan dan minum, brooder, pisau untuk memotong, nampan untuk alas saat memotong, grinder untuk menggiling pakan, sealer plastik untuk press plastik, 2 buah timbangan analitik dengan ketelitian 0,1 untuk menimbang ransum dan menimbang ayam, 1 buah timbangan analitik dengan ketelitian 0,01 untuk menimbang organ proventrikulus, ventrikulus, duodenum, jejunum dan ileum. Adapun ransum perlakuan dapat dilihat pada Tabel 1 .

Tabel 1.

Komposisi Bahan Pakan dan Kandungan Nutrien Ransum Penelitian

\begin{tabular}{|c|c|c|c|c|c|}
\hline \multirow[t]{2}{*}{ Bahan Pakan } & \multicolumn{4}{|c|}{ Komposisi Perlakuan Penambahan Pollard } & \multirow[b]{2}{*}{$\mathrm{T} 4$} \\
\hline & T0 & T1 & $\mathrm{T} 2$ & T3 & \\
\hline & \multicolumn{4}{|c|}{----------------------------(\%) } & \\
\hline Jagung & & 33,00 & 33,00 & 33,00 & 13,00 \\
\hline Pollard & & 40,00 & 0,00 & 0,00 & 0,00 \\
\hline Pollard Terolah & & 0 & 40,00 & 0 & 0 \\
\hline Pollard Terfermentasi & & 0,00 & 0,00 & 40,00 & 60,00 \\
\hline Bungkil Kedelai & & 25,00 & 25,00 & 25,00 & 25,00 \\
\hline VitMin Mix* & & 0,20 & 0,20 & 0,20 & 0,20 \\
\hline $\mathrm{NaCl}$ & & 0,25 & 0,25 & 0,25 & 0,25 \\
\hline L-Lysin HCL & & 0,10 & 0,10 & 0,10 & 0,10 \\
\hline DL-Metionin & & 0,10 & 0,10 & 0,10 & 0,10 \\
\hline $\mathrm{CaCO}_{3}$ & & 1,35 & 1,35 & 1,35 & 1,35 \\
\hline Jumlah & & 100,00 & 100,00 & 100,00 & 100,00 \\
\hline \multicolumn{6}{|l|}{ Kandungan Nutrien: } \\
\hline Protein Kasar (\%) & $20-22^{* *}$ & $20,91^{*}$ & $20,72 *$ & $20,62 *$ & $20,62 *$ \\
\hline Energi Bruto (kcal/kg) & $4100 * *$ & $3910,39^{1}$ & $3990,40^{1}$ & $4099,31^{1}$ & $4099,31^{1}$ \\
\hline Lemak Kasar (\%) & $5 * *$ & $2,25^{*}$ & $2,56^{*}$ & $2,34 *$ & $2,34 *$ \\
\hline Serat Kasar (\%) & $5^{* *}$ & $4,23^{*}$ & $4,41^{*}$ & $4,10^{*}$ & $4,10 *$ \\
\hline $\mathrm{Ca}(\%)$ & $0,9^{* *}$ & $0,84^{1}$ & $0,94^{1}$ & $0,91^{1}$ & $0,91^{1}$ \\
\hline $\mathrm{P}(\%)$ & $0,6^{* *}$ & $0,50^{1}$ & $0,58^{1}$ & $0,43^{1}$ & $0,43^{1}$ \\
\hline L-Lysin $\mathrm{HCl}$ & - & $0,80 * * *$ & $0,80 * * *$ & $0,80 * * *$ & $0,80 * * *$ \\
\hline DL-Metionin & - & $0,40 * * *$ & $0,40 * * *$ & $0,40 * * *$ & $0,40 * * *$ \\
\hline
\end{tabular}

Keterangan:

* Hasil analisis Laboratorium Ilmu Nutrisi dan Pakan Fakultas Peternakan dan Pertanian Universitas Diponegoro

** Label pakan BR-IAJ

*** Hasil perhitungan berdasarkan tabel komposisi bahan pakan Harihartadi (1997)

1 Hasil analisis Laboratorium Penelitian dan Pengujian Terpadu Universitas Gadjah Mada

Tahap Persiapan

Tahap persiapan meliputi proses pengolahan pakan yang diawali dengan pembuatan limbah kubis fermentasi, pembuatan pollard terolah secara fisik dan pembuatan pollard terolah secara fisik dan biologi serta persiapan kandang yaitu kandang disanitasi dengan pengapuran serta penyemprotan menggunakan desinfektan. Penelitian dilaksanakan selama 7 minggu dengan menggunakan rancangan acak lengkap (RAL) dengan 5 
perlakuan dan 3 ulangan. Perlakuan ransum selama pemeliharaan adalah sebagai berikut :

T0 $=$ Pakan Komersial BR-IAJ

$\mathrm{T} 1=$ Ransum dengan pollard tanpa terolah

$\mathrm{T} 2=$ Ransum dengan pollard terolah secara fisik

$\mathrm{T} 3=$ Ransum dengan pollard terolah fisik dan biologi $40 \%$

$\mathrm{T} 4=$ Ransum dengan pollard terolah fisik dan biologi $60 \%$

Prosedur pengambilan data diawali dengan pengambilan 4 ekor sampel ayam jantan yang diambil secara acak pada setiap perlakuan, kemudian ayam disembelih dan dicabut bulu, diambil organ pencernaan yaitu proventrikulus, ventrikulus, duodenum, jejunum dan ileum masing - masing organ ditimbang menggunakan timbangan analitik dengan ketelitian 0,01 gram.

Pengukuran bobot relatif organ pencernaan dilakukan dengan rumus sebagai berikut :

$\frac{\text { Berat Organ (g) }}{\text { Bobot Badan (g) }} \times 100 \%$

\section{Analisis Data}

Data dianalisis menggunakan analisis ragam atau analisis of variance
(ANOVA) dengan uji $\mathrm{F}$ pada taraf 5\% untuk mengetahui pengaruh perlakuan. Apabila menunjukkan pengaruh nyata, dilanjutkan uji beda Duncan (Steel dan Torie, 1996).

\section{HASIL DAN PEMBAHASAN Bobot Relatif Proventrikulus}

Hasil analisis ragam menunjukkan bahwa pemberian perlakuan tidak berpengaruh nyata $(\mathrm{P}>0,05)$ terhadap bobot relatif proventrikulus ayam broiler umur 7 minggu. Hasil pengamatan yang disajikan pada Tabel 2. bobot relatif proventrikulus ayam broiler umur 7 minggu berturut-turut adalah 0,62\%; $0,59 \% ; 0,65 \%$ dan $0,66 \%$. Hasil yang diperoleh lebih tinggi dari penelitian Noferdiman (2012), yaitu berkisar antara $0,50-0,53 \%$, namun bobot relatif proventrikulus yang dihasilkan pada penelitian ini masih tergolong normal bahkan melebihi. Berdasarkan penelitian Ukim et al. (2012), persentase bobot relatif proventrikulus yang normal berikisar antara 0,4-0,54\%.

Tabel 2.

Bobot Relatif Proventrikulus Ayam Broiler yang diberi Ransum Berbahan Pollard Terolah Selama 7 Minggu.

\begin{tabular}{|c|c|c|c|c|c|}
\hline \multirow[t]{2}{*}{ Ulangan } & \multicolumn{5}{|c|}{ Bobot Relatif } \\
\hline & T0 & $\mathrm{T} 1$ & $\mathrm{~T} 2$ & T3 & $\mathrm{T} 4$ \\
\hline & \multicolumn{5}{|c|}{$\ldots \%$} \\
\hline 1 & 0,45 & 0,77 & 0,71 & 0,76 & 0,53 \\
\hline 2 & 0,47 & 0,54 & 0,72 & 0,51 & 0,61 \\
\hline 3 & 0,42 & 0,70 & 0,74 & 0,60 & 0,57 \\
\hline Rerata & 0,45 & 0,67 & 0,72 & 0,62 & 0,57 \\
\hline
\end{tabular}


Pollard tanpa diolah mengandung polisakarida struktural tinggi, sehingga pemberiannya untuk unggas perlu dibatasi. Hal tersebut sesuai pendapat Utama et al. (2013) yang menyatakan bahwa pollard adalah limbah hasil industri pertanian dari penggilingan gandum sebagai sumber energi yang tinggi dan mengandung polisakarida struktural seperti selulosa, hemiselulosa, selobiosa, lignin dan silika, sehingga pollard sangat cocok diberikan untuk ternak ruminansia. Melalui pengolahan mampu meningkatkan nilai nutrisi pollard yaitu dengan cara memperbaiki struktur polisakarida. Pengolahan secara fisik dengan cara disteam menurut penelitian Wardani et al. (2004), mampu menghidrolisa hemiselulosa yang susah dicerna menjadi lebih sederhana, sehingga pemanfaatannya oleh unggas meningkat. Menurut Pantaya et al.
(2005), pakan yang diolah dengan pemanasan dari uap air mampu meningkatkan gelatinasi pati dan menurunkan zat anti nutrisi yang dapat mengurangi konsumsi pakan.

\section{Bobot Relatif Ventrilulus}

Hasil analisis ragam menunjukkan bahwa pemberian perlakuan berpengaruh nyata $(\mathrm{P}<0,05)$ terhadap bobot relatif ventrikulus ayam broiler pada umur 7 minggu. Hasil pengamatan yang disajikan pada Tabel 3. bobot relatif ventrikulus ayam broiler umur 7 minggu berturut-turut adalah $1,59 \%, 2,44 \%, 2,37 \%, 2,51 \%$ dan 2,19. Hasil yang diperoleh hampir sama dengan penelitian Noferdiman (2012) yang menunjukkan bahwa bobot relatif proventrikulus berkisar antara 2,03\%$2,41 \%$.

Tabel 3.

Bobot Relatif Ventrikulus Ayam Broiler yang diberi Ransum Berbahan Pollard Terolah Selama 7 Minggu.

\begin{tabular}{|c|c|c|c|c|c|}
\hline \multirow[t]{2}{*}{ Ulangan } & \multicolumn{4}{|c|}{ Perlakuan } & \multirow[b]{2}{*}{$\mathrm{T} 4$} \\
\hline & T0 & T1 & $\mathrm{T} 2$ & T3 & \\
\hline & \multicolumn{5}{|c|}{ …..............................................\%\%. } \\
\hline 1 & 1,01 & 2,69 & 3,14 & 2,50 & 2,24 \\
\hline 2 & 2,02 & 2,30 & 1,88 & 2,45 & 2,30 \\
\hline 3 & 1,75 & 2,33 & 2,08 & 2,57 & 2,03 \\
\hline Rerata & 1,59 & 2,44 & 2,37 & 2,51 & 2,19 \\
\hline
\end{tabular}

Pollard mengandung polisakarida struktural seperti selulosa, hemiselulosa, selebiosa, lignin dan silika yang dapat menurunkan kualitas bahan pakan tersebut. Pengolahan secara fisik dilakukan dengan tujuan mendegradasi serat kasar. Menurut Pantaya et al. (2005) pengolahan pakan dengan memanfaatkan panasnya uap air dapat meningkatkan gelatinasi pati dan menurunkan faktor anti nutrisi. Hasil penelitian Sulistiyanto et al.
(2017) menujukkan bahwa pollard yang disteam mampu mengubah struktur rafinosa, glukosa, manosa, arabinosa dan sukrosa, sehingga perlakuan pengolahan pollard secara fisik sangat diperlukan karena mampu meningkatkan nilai kebermanfaatan pollard untuk unggas. Kenyataan yang terjadi setelah dilakukan penelitian pada ayam broiler umur 7 minggu terhadap bobot relatif ventrikulus, belum menunjukkan pengaruh nyata. Hal 
ini diduga karena struktur kimia dari pollard berubah akibat dari proses steam yang dilakukan.

\section{Bobot Relatif Duodenum, Jejunum dan Ileum}

Hasil analisis ragam menunjukkan bahwa pemberian pollard terolah terhadap bobot relatif duodenum ayam broiler umur 7 minggu tidak berpengaruh nyata $(P>0,05)$. Hasil rerata pengamatan tercantum pada Tabel 4 . berturut-turut yaitu $1,55 \%, 2,16 \%, 1,74 \%, 1,75 \%$ dan $1,29 \%$. Hasil yang diperoleh lebih rendah dibandingkan dengan penelitian Iskandar (2004), menyatakan bahwa bobot duodenum yang diperoleh adalah berkisar antara 2,03\%-2,68\%.

Tabel 4.

Bobot Relatif Duodenum Ayam Broiler yang diberi Ransum Berbahan Pollard Terolah Selama 7 Minggu.

\begin{tabular}{cccccc}
\hline \hline \multirow{2}{*}{ Ulangan } & \multicolumn{5}{c}{ Perlakuan } \\
\cline { 2 - 6 } & T0 & T1 & T2 & T3 & T4 \\
\hline & $\ldots \ldots \ldots \ldots \ldots \ldots \ldots \ldots \ldots \ldots \ldots \ldots \ldots \ldots \ldots \ldots \ldots \ldots \ldots \ldots \ldots \ldots \ldots \ldots \ldots \ldots \ldots \ldots \ldots \ldots$ \\
\hline 1 & 0,95 & 2,04 & 2,06 & 2,31 & 1,41 \\
2 & 1,80 & 2,03 & 1,22 & 1,16 & 1,42 \\
3 & 1,89 & 2,40 & 1,93 & 1,78 & 1,05 \\
\hline Rerata & 1,55 & 2,16 & 1,74 & 1,75 & 1,29 \\
\hline
\end{tabular}

Pollard merupakan bahan pakan sumber energi yang tinggi, namun mengandung polisakarida struktural dalam jumlah yang banyak, sehingga jika diberikan langsung ke ternak unggas dapat menurunkan jumlah konsumsi pakan. Menurut Wardani et al. (2004), pemberian pollard tanpa diolah perlu dibatasi untuk mencegah terbentuknya gel kental di usus halus karena dapat menghambat penyerapan nutrien dan energi metabolisme semu (EMS). Pengolahan yang dilakukan melalui steaming atau perlakuan panas dengan uap air yang mampu mengubah struktur fisik dan kimia pollard. Hasil dari penelitian Pantaya et al. (2005) menunjukkan bahwa, suhu dan pemanasan dapat memicu terjadinya gelatinisasi pati, dan memecah zat anti nutrisi (arabinoxylan) yang dapat menghambat pencernaan dalam menyerap nutrien. Akan tetapi, hasil dari uji menggunakan ayam broiler umur 7 minggu terhadap bobot relatif duodenum belum memiliki pengaruh yang nyata. Hal tersebut diduga karena pada saat pemanasan dan penambahan air terjadi perubahan struktur fisik dan kimia pollard, karena adanya proses gelatinasi pati. Hal tersebut sesuai dengan penelitian Sulistiyanto et al. (2017) yang menunjukkan bahwa, steam pollard dapat memicu terjadinya proses gelatinasi pati, sehingga kadar rafinosa, glukosa manosa, arabinosa dan sukrosa juga berubah.

Berdasarkan hasil uji statistik pada perlakuan pollard terolah secara fisik (steaming) dan biologis (fermentasi) tidak berpengaruh nyata $(\mathrm{P}>0,05)$ terhadap bobot relatif jejunum (Tabel 5.) ayam broiler umur 7 minggu. Hasil yang diperoleh berturut-turut adalah 3,28\%, $3,78 \%, 3,33 \%, 4,01 \%$ dan $4,44 \%$. Rerata yang diperoleh sama dengan hasil penelitian dari Iskandar (2004) yang menyatakan bahwa bobot relatif jejunum adalah $2,70 \%$. 
Tabel 5.

Bobot Relatif Jejunum Ayam Broiler yang diberi Ransum Berbahan Pollard Terolah Selama 7 Minggu.

\begin{tabular}{cccccc}
\hline \hline \multirow{2}{*}{ Ulangan } & \multicolumn{5}{c}{ Perlakuan } \\
\cline { 2 - 6 } & T0 & T1 & T2 & T3 & T4 \\
\hline & $\ldots \ldots \ldots \ldots \ldots \ldots \ldots \ldots \ldots \ldots \ldots \ldots \ldots \ldots \ldots \ldots \ldots \ldots \ldots \ldots \ldots \ldots \ldots \ldots \ldots \ldots \ldots \ldots \ldots \ldots \ldots \ldots \ldots \ldots \ldots \ldots \ldots \ldots \ldots \ldots \ldots \ldots \ldots \ldots \ldots \ldots \ldots \ldots \ldots \ldots \ldots \ldots \ldots \ldots \ldots \ldots \ldots \ldots$ \\
2 & 2,85 & 4,59 & 3,59 & 4,83 & 3,21 \\
3 & 3,40 & 2,86 & 3,59 & 3,41 & 4,31 \\
\hline Rerata & 3,58 & 3,90 & 2,82 & 3,80 & 5,80 \\
\hline
\end{tabular}

Penelitian ini menggunakan pollard yang diolah dengan cara fisik melalui steaming dan biologis (fermentasi) dengan tujuan untuk meningkatkan nilai nutrisi pollard. Kandungan polisakarida struktual pada pollard yang tinggi menurunkan konsumsi pakan jika ditambahkan dalam ransum. Hal tersebut sesuai dengan pendapat Utama et al. (2013) yang menyatakan bahwa pollard memiliki sifat bulky, laxantive dan palatable jika diberikan dengan jumlah 40 - 50\% sehingga mampu menurunkan jumlah konsumsi pakan. Pengolahan yang dilakukan melalui steaming atau perlakuan panas dengan uap air yang mampu mengubah struktur fisik dan kimia pollard. Hasil dari penelitian Pantaya et al. (2005) menunjukkan bahwa, suhu dan pemanasan dapat memicu terjadinya gelatinisasi pati, dan memecah zat anti nutrisi (arabinoxylan) yang dapat menghambat pencernaan dalam menyerap nutrien. Kandungan arabinoksilan pada pollard yang tinggi mampu menghalangi proses penyerapan asam amino dan mineral di dalam saluran pencernaan. Hal tersebut sesuai dengan pendapat Wardani et al. (2004) menyatakan bahwa, arabinoksilan tidak dapat dicerna oleh ternak unggas karena bahan tersebut dapat berbentuk gel kental di usus halus, sehingga menghambat penyerapan nutrien dan energi metabolis semu (EMS). Akan tetapi, hasil dari uji menggunakan ayam broiler umur 7 minggu terhadap bobot relatif jejunum belum memiliki pengaruh yang nyata. Hal tersebut diduga karena pada saat pemanasan dan penambahan air terjadi perubahan struktur fisik dan kimia pollard, karena adanya proses gelatinasi pati. Hal tersebut sesuai dengan penelitian Sulistiyanto et al. (2017) yang menunjukkan bahwa, steam pollard dapat memicu terjadinya proses gelatinasi pati, sehingga kadar rafinosa, glukosa manosa, arabinosa dan sukrosa juga berubah.

Hasil uji statistik pada pemberian perlakuan pollard terolah secara fisik (steaming) dan biologis (fermentasi) tidak berpengaruh nyata $(\mathrm{P}<0,05)$ terhadap bobot relatif ileum yang dapat dilihat pada Tabel 6. pada ayam broiler umur 7 minggu. Hasil yang diperoleh berturutturut adalah 2,77\%,2,87\%,2,94\%, 3,13 dan $3,54 \%$. Rerata yang diperoleh lebih rendah dari hasil penelitian Iskandar (2004) yang menyatakan bahwa bobot relatif ileum adalah $1,86 \%$. 
Tabel 6.

Bobot Relatif Ileum Ayam Broiler yang diberi Ransum Berbahan Pollard Terolah Selama 7 Minggu.

\begin{tabular}{|c|c|c|c|c|c|}
\hline \multirow[t]{2}{*}{ Ulangan } & \multicolumn{4}{|c|}{ Perlakuan } & \multirow[b]{2}{*}{$\mathrm{T} 4$} \\
\hline & T0 & T1 & $\mathrm{T} 2$ & T3 & \\
\hline \multicolumn{6}{|c|}{ 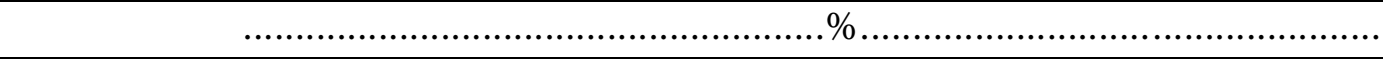 } \\
\hline 1 & 3,28 & 3,61 & 3,05 & 3,58 & 4,03 \\
\hline 2 & 2,21 & 2,12 & 2,99 & 2,73 & 2,52 \\
\hline 3 & 2,83 & 2,88 & 2,79 & 3,08 & 4,08 \\
\hline Rerata & 2,77 & 2,87 & 2,94 & 3,13 & 3,54 \\
\hline
\end{tabular}

Pollard mengandung polisakarida struktural seperti selulosa, hemiselulosa, selebiosa, lignin dan silika yang dapat menurunkan kualitas bahan pakan tersebut. Kandungan arabinoksilan pada pollard yang tinggi mampu menghalangi proses penyerapan asam amino dan mineral di dalam saluran pencernaan. Hal tersebut sesuai dengan pendapat Wardani et al. (2004) menyatakan bahwa, arabinoksilan tidak dapat dicerna oleh ternak unggas karena bahan tersebut dapat berbentuk gel kental di usus halus, sehingga menghambat penyerapan nutrien dan energi metabolis semu (EMS). Pengolahan secara fisik dilakukan dengan tujuan mendegradasi serat kasar. Menurut Pantaya et al. (2005) pengolahan pakan dengan memanfaatkan panasnya uap air dapat meningkatkan gelatinasi pati dan menurunkan faktor anti nutrisi.

Pollard yang diolah secara biologis menurut penelitian Utama et al. (2013), difermentasi selama 4 hari dengan limbah sayur menghasilkan total bakteri asam laktat (BAL) $3 \times 10^{4} \mathrm{CFU} / \mathrm{g}$ dan total jamur, terdiri dari khamir Saccharomyces cerevesiae dan kapang Rhizopus sp. sebanyak $13 \times 10^{3} \mathrm{CFU} / \mathrm{g}$. Mikroorganisme dibutuhkan oleh tubuh untuk membantu mendegradasi selulosa kompleks menjadi senyawa yang lebih sederhana, sehingga mempermudah penyerapan nutrien. Menurut Utama et al. (2018), Lactobacil- lus brevis dan Lactobcillus plantarum berperan aktif dalam menghidrolisis selulosa menjadi glukosa karena memiliki aktivitas enzim selulase. Namun, hasil penelitian secara in vitro menunjukkan pengaruh yang tidak berbeda nyata terhadap bobot relatif ileum. Hal tersebut diduga karena proses penyerapan nutrien telah dilakukan oleh duodenum dan jejunum. Selain itu, pH ileum yang cenderung netral memungkinkan jumlah bakteri asam laktat menurun, sehingga pemberian pollard terolah tidak berpengaruh pada organ ini. Menurut Jamilah et al. (2014), ileum adalah bagian usus halus yang memiliki $\mathrm{pH}$ netral yaitu 6-7. Menurut Utama et al. (2013) bahwa bakteri asam laktat memerlukan suasana asam untuk tumbuh dan berkembangbiak.

\section{KESIMPULAN}

Berdasarkan hasil penelitian dapat disimpulkan bahwa pemberian pollard terolah secara fisik dan biologis belum mampu meningkatkan semua bobot relatif organ pencernaan ayam broiler umur 7 minggu. Pada organ proventrikulus pakan perlakuan mampu meningkatkan bobot relatif organ pencernaan ayam broiler, namun bobot relatif proventrikulus yang dihasilkan masih tergolong normal. 


\section{SARAN}

Pengukuran bobot organ ayam broiler perlu dilakukan per minggu untuk mengetahui laju peningkatan bobot relatif organ pencernaan yang optimal, sehingga diperoleh data maksimal pertumbuhan organ ayam broiler secara tepat. 


\section{DAFTAR PUSTAKA}

Iskandar, S. 2004. Respon pertumbuhan dan perkembangan alat pencernaan ayam anak silangan pelung $\mathrm{x}$ kampung terhadap kandungan protein ransum. J. Ilmu Ternak dan Veteriner. 9(4): 217-225.

Noferdiman. 2012. Penggunaan Azolla microphylla fermentasi sebagai pengganti bungkil kedelai dalam ransum terhadap bobot organ pencernaan aya broiler. J. Penelitian Universitas Jambi Seri Sains. 1(14): 49-56.

Nurdianto, M., C.S. Utama dan S. Mukodiningsih. 2015. Total jamur, jenis kapang dan khamir pellet ayam kampung super dengan penambahan berbagai level pollard berprobiotik. Agripet. 1(15): 79-84.

Pantaya, D., Nahrowi dan L.A. Sofyan. 2005. Penambahan enzim cairan rumen pada pakan berbasis wheat pollarddengan proses pengolahan steam pelleting pada performans broiler. Media Kedokteran Hewan. 21 (1): 35-38.1

Raharjo dan Adisasmita.2000. Pengembangan Wilayah Konsep dan Teori.Yogyakarta.:Graha Ilmu

Rasyaf, M. 2008. Panduan Beternak Ayam Pedaging. Penebar Swadaya, Jakarta.

Rukminasih, dan Harjosworo. 2000. Peningkatan Produksi Ternak Unggas. Penebar Swadaya, Jakarta.

Sulistiyanto, B., S. Kismiati dan C.S. Utama. 2017. Perubahan kadar rafinosa, glukosa, manosa, arabinosa dan sukrosa wheat pollard akibat lama steam dan penambahan air yang berbeda. J. Litbang Prov. Jawa Tengah. 15 (2): 162-169.

Ukim C.I., Ojewola, G.S. and Obun, C.O., Ndelekwute, $\quad$ E.N. 2012. Performance and carcass and organ weights of broiler chicks fed graded levels of acha grains (Digitaria exills). Journal of Agriculture and Veterinary Science. 1 (2): 28-33.

Utama, C.S., B. Sulistiyanto dan B.E. Setiani. 2013. Profil mikrobiologis pollard yang difermentasi dengan ekstrak limbah pasar sayur pada lama peram yang berbeda. J. Agripet. 13 (2): 26-30.

Utama, C.S., B. Sulistiyanto, and S. Kismiati. 2017. The effects of water addition and steaming duration on starch composition of wheat pollard. Reaktor. 17(4): 220-224.

Utama, C.S., Zuprizal, C. Hanim dan Wihandoyo, 2018 . Isolasi dan identifikasi bakteri asam laktat selulolitik yang berasal dari jus kubis terfermentasi. Jurnal Aplikasi Teknologi Pangan 7(1):1-6.

Utama, C.S., Zuprizal, C. Hanim dan Wihandoyo, 2018 ${ }^{\mathrm{b}}$. Probiotic testing of Lactobacillus brevis and Lactobacillus plantarum from fermented cabbage waste juice. Pak. J. Nutr. 17(7):323-328.

Wardani, W., N. Ramli dan W. Hermana. 2004. Ketersediaan energi ransum yang mengandung wheat pollard hasil olahan enzim cairan rumen yang diproses secara steam pelleting pada ayam broiler. Media Peternakan 27 (3): 123-128.

Yuwanta, T. 2004. Dasar Ternak Unggas. Kanisisus, Yogyakarta 